\author{
M. Abdrakhim \\ Al-Farabi Kazakh National University, Almaty, Kazakhstan \\ (E-mail:abdrakhim_91@mail.ru)
}

\title{
Kazakh translators of the Semirechensk oblast
}

\begin{abstract}
This article discusses the activities of Kazakh translators who served in the administration structure of the Semirechensk region. The author examined the positions of regional officials on Kazakh translators, studied the social origins of local translators, their salaries and the motives for joining the civil service. Also, this article analyzes the image of Kazakh translators who served in the regional administration.
\end{abstract}

Keywords: translator, Semirechensk oblast, kazakh officials, regional administration, rank, position, kazakh translators.

\section{Introduction}

In the second half of the XIX century, significant changes occurred on the territory of Kazakhstan. The Russian government in reforms of 1867-1868 declared the land of the Kazakh people the property of the Empire, completely took all the levers of control into its own hands. Accordingly, the political, economic, and cultural aspects of Kazakh society were transformed and began to take on a different character.

At the same time, the tsarist government was constantly searching for some new, effective methods and tools for managing the Kazakh people. It was for purpose that the Russian Empire regularly conducted experiments aimed at controlling the Kazakhs. One of these experiments can be attributed to the policy of the Empire to create its own corps of officials of different ranks from the local residents, the native population of the Steppe.

One of the parts of such a mechanism of state administration was the corps of translators, without whose participation it is impossible to imagine the history of Kazakh-Russian relations in the XIX century. They were part of the relationship between the Russian government and local Kazakhs, as they provided a link between the Russian administration and the population.

\section{Relevance of the problem}

In the second half of the XIX century, translators of the Semirechensk oblast played an important role in administrative affairs. The connection of the Russian administration with the local population depended on them. Therefore, all administrative units had full-time Kazakh translators.

Currently, the problems of Kazakh translators of the Semirechensk oblast are very relevant in modern historical science, since this topic has always been studied in the context of all regions of Kazakhstan or in the aggregate of all Kazakh officials of the region. It has not been considered as a separate research topic before. Therefore, the analysis of the activities of Kazakh translators in the Semirechensk oblast is very important for historical science.

Also, the problem studied in this article is relevant from the point of view of the new social history. Because consideration of questions on the activity of translators will give an opportunity to see certain social changes in the Kazakh society in the second half of the XIX - early XX centuries from a new position, and also help in their interpretation.

\section{The purpose and objectives of the study}

Based on the relevance of problem, the author in this study aims to show a socio - cultural portrait of translators who served in the administrative apparatus of the Semirechensk oblast in the second half of the XIX - early XX centuries. To achieve this goal, the following tasks are set:

- to consider the importance of the position of translators from the opinions of Russian officials;

- reveal the role of translators in the Semirechensk oblast;

- identify their socio-cultural portrait by describing their education, social origin and ranks;

- show the perception of the local population about officials-translators from among the Kazakh people. 


\section{Research methods}

In article, the author used methods that helped to review the activities of Kazakh translators in the Semirechensk oblast. In particular, to indicate the role of Kazakh translators in this region, a systematic approach was used, with the help of which the positions of officials of the colonial administration in relation to translators were considered not only in this area, but also throughout the Governor-General's office. The relations of Russian officials were defined not only to certain officials, but also to the position of translators.

It was also important to use the method of historical and comparative analysis. This approach helped to identify new features in the activities of Kazakh translators in the region. Comparison of their education levels, social origins, personal motives for entering the public service, service records and awards made it possible to see their socio-cultural portrait in the Kazakh society of the region.

In addition, the «New social history», which is based on the principles of interdisciplinarity, plays an important role in the study. According to this scientific approach, it is very important to study social mobility, which is considered as the most important factor for determining social boundaries within a society. Therefore, the use of the «New social history» helped to identify new social transformations in the Kazakh society of the Semirechensk oblast. The definition of changes in mental representations, values, customs, and behaviors in the Kazakh society of the region made it possible to consider the role of Kazakh translators from a new perspective. Also, using this research method, images of Kazakh translators were identified both in literature and in historical studies.

\section{The source base of the problem}

The source basis of this problem can be divided into 5 following groups:

1. The most important and extensive database of source materials on Kazakh translators of the Semirechensk oblast is, obviously, the archival documents of the 44 fund, «Semirechensk Oblast Administration» («Semirechenskoe Oblastnoe Pravlenie») of the Central State Archive of the Republic of Kazakhstan. They contain official documents of the office manager of the Semirechensk Oblast Administration, including various documents about translators in the region. Their nature covers from simple private petitions to state-important documents on the appointment of translators, their awards and other issues.

2. The second group of sources of the investigated topic includes legislative acts of the Russian Empire. «Temporary Provisions on the Administration of the Semirechensk and Syrdarya Oblasts» of 1867 [1] and «Provisions on the Administration of the Akmola, Semipalatinsk, Semirechensk, Ural and Turgai Oblasts» or «Steppe Provisions» [2]. They contain the goals and objectives of the presence of translators in the region and state, job descriptions.

3. The next group of sources on Kazakh translators is official reference books, calendaring addresses and lists of citizens who were in the ranks of the public service. Such reference materials covered information on the officials of the region, their positions, and the time they served in management. Among such data there is also information on translators, including Kazakh translators of the Semirechensk region. So, for example, «Address-calendar of employees in the Semirechensk region for 1897» [3] contains information about the leaders of the civil and military departments. Since the next 1898, this reference book was already called as «The Memorial Book and the Address-Calendar of the Semirechensk Region» [4]. Later, such books were published as early as 1900 [5], 1901 [6] and 1905 [7]. And in 1902, the «List of persons of civil and other departments serving in the Semirechensk region» was published [11]. The contents of such reference materials published by the statistical committee of the region contain information on Kazakh translators of the region for the indicated years. In addition, similar information is also found in the «Lists of persons of civil and religious departments serving in the Turkestan Territory» for 1900 [12], 1901 [13] and 1902 [14].

4. The fourth group of sources includes many circulars and orders of the region's leadership and the governor general on the problems of translators, which were published in the local periodical. For example, the «Compendium of materials on the study of native languages by civil servants of the Turkestan region» contains the positions of colonial officials in relation to local translators, as well as discussions about the need for Kazakh translators in the region in general [12]. And drawn up by N.P. Ostroumov, signed by Governor General N.O. Rosenbach's «Instruction for Official Translators of the Turkestan region» [13] gives all translators in the region «uniform methods of translation» of official documents. 
5. The fifth group of sources of the problem includes historical research of the XIX and early XX centuries. So the works of I.I. Kraft [14], P.P. Rumyantsev [15], G.K. Gins [16] have descriptive information regarding Kazakh translators. And the reports of Senator K.K. Pahlen [17], [18] contain information on the staffing number of Kazakh translators in the Semirechensk region. In addition, the works of Russian Orientalist officials V.P. Nalivkina [19], N.S. Lykoshin [20] provide very important information on the reconstruction of the images of local translators of the Turkestan region as a whole.

\section{The historiography of the problem}

Native historiography. The problem of studying translators in the Semirechensk oblast as a separate object of research has not been considered before. It has always been studied in the context of all regions of Kazakhstan or indirectly reflected in the works of some native and foreign scientists.

In Soviet times, this topic was practically not studied. It was only described in fragments in some works of the Soviet period. For example, in the work of Turar Ryskulov, «The Revolt of the natives in Central Asia in 1916», the «native» translators of the Semirechensk oblast were described as «elements attached to the administration», who «in their own way exploited and taxed «voluntarily» or «forcibly» the settled workers and nomadic people» [21;99]. The author also called local translators as «the link of the native administration» in the robbery of the common people. A similar point of view is shown in the work of S.D. Asfendiyarov. The author calls the translators as «colonial rabble» and sharply criticizes their activities $[22 ; 15]$.

In the years of independence, native historians began to study the problem of Kazakh officialdom. Modern scientists dealing with issues of Kazakh officialdom using different, already new approaches try to explain this problem from different sides: in the context of regions of Kazakhstan, by activities, ranks, numbers of Kazakh officials or other criteria. So the problem of studying bureaucracy in the Semirechensk oblast was touched upon in the research of professor G.S. Sultangaliyeva, where she presented a scientific study of the formation and functioning of bureaucracy on the territory of the entire steppe space. She also systematized materials about Tatar translators, interpreters, and letter keepers in the Kazakh steppe in the XVIII-XIX centuries [23].

Another historian, M.K. Koigeldiyev, in his research on the history of Semirechye as part of the Russian Empire, described the staff of translators in the region [24]. Also historian Z.Sh. Makazhanova describes training for managerial staff in the field [25], and A. Aitmagambetov in his research in the context of all regions of Kazakhstan in the XIX - early XX centuries, describes in detail the characteristics of the Kazakh students, the activities of the Kazakh translators Semirechensk area in the professional, social and political relations [26].

Furthermore, in the study of N.A. Adelbayeva on the problems of school education in the Semirechensk and Syrdarya regions in the XIX - early XX centuries, the activities of Russian-native schools in terms of training translators and scribes for the tsarist administration from the indigenous population of Semirechye are considered [27]. In the research work of Z.G. Saktaganova, the author describes the Kazakh bureaucracy in the Semirechensk oblast in the early XX century and shows the image of Kazakh officials of that time [28].

In the work of S.K. Uderbayeva on the Kazakh bureaucracy of the Semirechensk oblast, there are data on translators of this region. In particular, the author describes the life and activities of the Kazakh translators in the area such as S. Sabatayev and I. Tergeusizov [29]. Another researcher Sh.A. Ilyassov in his dissertation also examines the activities of translators of the Semirechensk oblast, but only during the period when the region was part of the Steppe general-governorship [30].

In the studies of post-Soviet scientists. This issue is also covered in the works of researchers of postSoviet countries engaged in the study of problems of colonial Turkestan. Thus, in the work of the Russian researcher M.E. Shushkova on the organization of management of Turkestan in the early XX century, the author describes the partial positions of Russian administrators of Turkestan in relation to «the contingent of local translators» $[31 ; 170]$.

In the work of O.L. Sumarokova «On the issue of linguistic training of administrative employees of the Turkestan region», the author analyzes «the reasons for the indifference of Russian officials to linguistic and extralinguistic issues» in the Turkestan region [32]. Here, a researcher from Kyrgyzstan examines the role of local translators of the Semirechensk oblast, as well as the entire region, in the colonial administration of the Russian Empire. But the scientist from Uzbekistan Alimjanov Bakhtiyor in his work gives examples of 
attempts by the Russian administration in the region to increase the «prestige of representatives of the military-people's administration in the eyes of the natives», including translators [33].

The scientist Vladimir Ploskikh also describes the role of local translators in the Semirechensk oblast in the early XX century. The author pays special attention to the translator Abdikerim Sydykov, who served as a verbal translator of the Pishpek county administration. As the author notes, this translator, A. Sydykov, was able to save many Kyrgyz during the 1916 uprising only because he «secretly notified the rebels about the upcoming punitive operations» as an employee of the state apparatus [34].

The article by Sh.A. Kuliyeva and D.V. Tavberidze, «Translation in the Central Asian region: pages of history (XVI-XIX centuries)», describes the stages of formation of translation activities in the Kazakh steppe. The periods of Kazakh-Russian relations and the role of translators in them are also highlighted. In addition, the authors give opinions about the image of Kazakh officials of the colonial administration [35].

Another interesting work on the activities of local translators in the Turkestan region is the study of the Uzbek scientist B. Babajanov. In his opinions about the official language and translation in the Turkestan region, you can see the image of «native» translators not only in the Semirechensk oblast, but also in the entire Turkestan region [13; 600-606].

Foreign historiography. In addition, the issue of attracting Kazakh translators in the Semirechensk oblast to the administrative affairs of the Russian government was also touched upon indirectly in the works of foreign historians. For example, the theme of the translators involved in the work of Talent Mawkanuly and Virginia Martin. In their research, they verified translated documents to local translators in the Kazakh steppe [36]. Another foreign scholar Adeeb Khalid, in his work «Culture and Power in Colonial Turkestan», describing the activities of «Russian-native schools», notes the process of forming «useful citizens of Russia», which included translators [37]. And in the work of Ian Campbell, local translators of the entire Kazakh land were considered as «intermediaries» between the population and the colonial apparatus of the Russian Empire [38].

\section{Positions of Russian officials of the region in terms of Kazakh translators}

In the second half of the XIX century, the tsarist administration of Turkestan had problems in terms of communication with the local population, since the number of Russian officials who knew «native dialects» was very small. And this problem drew attention from the heads of the region. One of the first to sound the alarm was the Governor-General of the Turkestan, Konstantin Petrovich Kaufman (1818-1882). He noted the problem of ignorance of the languages of «natives» by members of the administration of the Turkestan region. In his opinion, «the unavoidable presence of translators» only did that to distance Russian officials from the «Turkic-speaking peoples» [39; 67]. Therefore, the General encouraged his colleagues to study the languages of local peoples.

Another governor general of the Turkestan region, Nikolai Ottonovich Rosenbach (1884-1889), also drew attention to the problem of replacing local translators by mastering «native» languages by Russian officials. In his «Notes» he said that he «demanded from the ranks of the Russian administration, which had direct relations with the natives, the study of native dialects» [40;192].

Sergei Mikhailovich Dukhovsky, Governor-General of Turkestan Governor-General in 1898-1901, in circular No. 10 published in August 1898 recognized the fact that officials of his apparatus were «not sufficiently familiar» with the dialects of local peoples [32; 172].

The Turkestan Governor-General Dean Ivanovich Subbotich (1905-1906) writes in a letter to Minister of War Rediger: «We have been possesed Turkestan for forty years, and until now, administration officials who know at least a few indigenous languages can be counted on the fingers. There are even fewer of them in the judicial department» [35;314]. Calling this state of affairs «fatal» and «extremely abnormal», D.I. Subbotich ordered the establishment of a commission to consider measures «by which employees could be encouraged to learn local languages» $[12 ; 2]$. The Governor General also initiated a public discussion on this issue on the pages of the «Turkestanskie vedomosti». However, all his efforts were inconclusive.

The next Governor-General of Turkestan Governor-General Nikolai Ivanovich Grodekov (1906-1908), who «did not want to be a passive and trustful listener of the translators who didn't always accurately translate native language», he himself learned the local languages and demanded that all officials of the Russian administration follow his example, «insisting on their conscious mastery of the language» $[41 ; 88]$. He also repeatedly pointed out that Russian officials do not speak the languages of local peoples, which encourages the use of translators. 
From the above it is obvious that the administration of the Turkestan governor-general experienced the problem of a shortage of personnel from among Russian officials who know the languages of the peoples living in the region. And this problem was almost throughout the entire existence of the governor general. All the initiatives of the first persons of the region to demand the study of local dialects were unsuccessful and did not yield any positive results. An inside look at the reasons why Russian officials didn't learn the local languages showed that there are various explanations for this. One of the prominent Russian officials of the Turkestan region N.S. Lykoshin noted that some of them did not have the patience to «learn an alien language just for the sake of pure knowledge», and for others it was impossible to learn languages due to living conditions and official work [20;34]. And sometimes some officials simply did not have the proper motivation, they «did not know and did not want to study, being satisfied with the services of... translators,» as in the case of the Russian officer V.P. Nalivkin [19;67]. That is why for such cases N.S. Lykoshin proposed to motivate them to learn the language with the help of financial cncouragement and the requirement to have at least 3-year knowledge of the required language in order to occupy an official post $[20 ; 34,35]$. A Russian official, orientalist scientist and inspector of public schools of the Turkestan region N.P. Ostroumov described the majority of Russians who served in the Turkestan governor-general as bad culture promoters and acknowledged the unsuccessful attempts of the Russian administration not to use the services of local translators by replacing them with Russian translators [32; 172].

Thus, the administration of the Turkestan governor general due to the scarcity of Russian translators of «native» languages used the services of translators from the local population. This circumstance contributed to the increasing role of Kazakh translators. Because it was the Kazakh translators, on the one hand, that compensated for the ignorance of Russian officials of «native dialects», on the other hand, strengthened the mechanisms for incorporating Kazakh officials into a unified management system of the Russian Empire.

\section{Kazakh translators of Semirechensk oblast: staff and number}

In the second half of the XIX century in the Semirechensk oblast, Kazakh translators began to replace Tatars in the public service. Kazakh specialists who were educated in Russian-native schools, gymnasiums and universities in Russia began to find jobs in the management of counties and regions. They performed the role of verbal and written translators in the management system and held such positions provided for by law.

So, for example, according to the «Steppe Provisons» of 1891, there were 3 translators in the Semirechensk oblastal government: one translator of Manchurian and Chinese, two translators of native languages. Since the translators of Manchu and Chinese languages were usually graduates of military institutes who completed Oriental language courses, the Kazakhs could not occupy such a position here. But they were translators of «native languages», which, according to the Provisions, were equated in office and in sewing uniforms for grade IX, and for retirement the rank VII. Their maintenance per year was 1600 rubles (800 rubles per one) [2; 144]. Also, according to Article 41 of these Provisions, there were also two full-time translators of native languages in uezd administrations. One of them was written, at the chancellery, and the other was verbal, in case of business trips with management ranks [2; 49]. In addition, the practice of hiring translators by uezd doctors, which had existed since 1881 by order of the administration of the Turkestan region, continued [2; 54].

A detailed description of the positions of translators was noted in the reports of count K.K. Pahlen, who conducted a senatorial audit in 1908-1909 in the Turkestan region. According to his report, 36 full-time officials served in the regional administration of the Semirechensk oblast, 3 of whom were translators [17; 109]. And the uezd administrations of the Semirechensk oblast had two translators in the state: written and verbal translators. If the translator belonged to the XIV class by position, and by pension to the IX category of officials, then the verbal one was not included in such ranks [18; p. 161].

In addition, the names of Kazakh translators of the Semirechensk oblast who served in the management of counties and regions can be found in the address-calendars and lists of «civil servants and other departments serving in the Semirechensk oblast». Having considered their data for 1897, 1898, 1900, 1901, 1902 and 1905, which contain the names of specific translators with their place of work and position, it is possible to identify the following Kazakh translators for this period: 
Cha r t no. 1 .

\begin{tabular}{|c|c|c|c|c|c|c|c|}
\hline 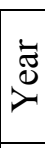 & $\begin{array}{c}\text { Oblast } \\
\text { Administra- } \\
\text { tion } \\
\end{array}$ & Vernyi uezd & Kopal uezd & Lepsinsk uezd & $\begin{array}{l}\text { Pishpek } \\
\text { uezd }\end{array}$ & $\begin{array}{c}\text { Pzhevalsk } \\
\text { uezd }\end{array}$ & $\begin{array}{c}\text { Dzharkent } \\
\text { uezd }\end{array}$ \\
\hline$\widehat{\infty}$ & $\begin{array}{l}\text { Turdybek } \\
\text { Syrtanov; } \\
\text { Assylkhodzha } \\
\text { Kurmanbayev }\end{array}$ & $\begin{array}{l}\text { Bakiy } \\
\text { Chalymbekov }\end{array}$ & $\begin{array}{l}\text { Kalygul } \\
\text { Chigirov }\end{array}$ & $\begin{array}{l}\text { Nur-Ahmed } \\
\text { Nurzhanov; } \\
\text { Abush } \\
\text { Nurzhanov }\end{array}$ & $\begin{array}{l}\text { Yaguda } \\
\text { Kushukov; } \\
\text { Ibragim } \\
\text { Nogayev }\end{array}$ & $\begin{array}{l}\text { Muhamed } \\
\text { Ali } \\
\text { Muratalin }\end{array}$ & $\begin{array}{l}\text { Kalmyky } \\
\text { Bulatov }\end{array}$ \\
\hline $\begin{array}{l}\infty \\
\infty \\
\infty\end{array}$ & $\begin{array}{l}\text { Turdybek } \\
\text { Syrtanov; } \\
\text { Assylkhodzha } \\
\text { Kurmanbayev }\end{array}$ & $\begin{array}{l}\text { Bakiy } \\
\text { Chalymbekov }\end{array}$ & $\begin{array}{l}\text { Abush } \\
\text { Nurzhanov }\end{array}$ & $\begin{array}{l}\text { Nur-Ahmed } \\
\text { Nurzhanov }\end{array}$ & $\begin{array}{l}\text { Kalygul } \\
\text { Chigirov }\end{array}$ & $\begin{array}{l}\text { Yaguda } \\
\text { Kushukov }\end{array}$ & $\begin{array}{l}\text { Dzhumadyl } \\
\text { Koshagulov }\end{array}$ \\
\hline \& & $\begin{array}{l}\text { Turdybek } \\
\text { Syrtanov; } \\
\text { Kalygul } \\
\text { Chigirov }\end{array}$ & $\begin{array}{l}\text { Bakiy } \\
\text { Chalymbekov }\end{array}$ & $\begin{array}{l}\text { Abush } \\
\text { Nurzhanov }\end{array}$ & $\begin{array}{l}\text { Nur-Ahmed } \\
\text { Nurzhanov }\end{array}$ & $\begin{array}{l}\text { Satylgan } \\
\text { Sabatayev }\end{array}$ & \begin{tabular}{|l} 
Yaguda \\
Kushukov
\end{tabular} & - \\
\hline ஓ̊ & $\begin{array}{l}\text { Turdybek } \\
\text { Syrtanov; } \\
\text { Kalygul } \\
\text { Chigirov }\end{array}$ & $\begin{array}{l}\text { Bakiy } \\
\text { Chalymbekov }\end{array}$ & $\begin{array}{l}\text { Abush } \\
\text { Nurzhanov }\end{array}$ & $\begin{array}{l}\text { Dzhuman } \\
\text { Tyshkambayev }\end{array}$ & $\begin{array}{l}\text { Satylgan } \\
\text { Sabatayev }\end{array}$ & $\begin{array}{l}\text { Yaguda } \\
\text { Kushukov }\end{array}$ & - \\
\hline §̊ & $\begin{array}{l}\text { Turdybek } \\
\text { Syrtanov; } \\
\text { Kalygul } \\
\text { Chigirov }\end{array}$ & $\begin{array}{l}\text { Bakiy } \\
\text { Chalymbekov }\end{array}$ & - & $\begin{array}{l}\text { Dzhuman } \\
\text { Tyshkambayev }\end{array}$ & - & $\begin{array}{l}\text { Yaguda } \\
\text { Kushukov }\end{array}$ & $\begin{array}{l}\text { Satylgan } \\
\text { Sabatayev }\end{array}$ \\
\hline ڤ̊ & $\begin{array}{l}\text { Kalygul } \\
\text { Chigirov }\end{array}$ & $\begin{array}{l}\text { Bakiy } \\
\text { Chalymbekov }\end{array}$ & $\begin{array}{l}\text { Dzhumadyl } \\
\text { Koshagulov; } \\
\text { Assylkhodzha } \\
\text { Kurmanbayev }\end{array}$ & $\begin{array}{l}\text { Dzhuman } \\
\text { Tyshkambayev }\end{array}$ & $\begin{array}{l}\text { Muhamed } \\
\text { Ali } \\
\text { Muratalin; } \\
\text { Naizabek } \\
\text { Tulin } \\
\end{array}$ & $\begin{array}{l}\text { Yaguda } \\
\text { Kushukov }\end{array}$ & $\begin{array}{l}\text { Satylgan } \\
\text { Sabatayev; } \\
\text { Ibragim } \\
\text { Zhainakov }\end{array}$ \\
\hline
\end{tabular}

As we can see in this table, Kazakh officials were in the structure of the oblast administration and all uezd offices for the specified period. It can also be concluded that in some uezds the translators were stable, the same persons remained, while in some they changed frequently. There are many petitions, applications and other documents in the materials of the archive of the Central state archive of the Republic of Kazakhstan that explain such frequent movement. Here, the reasons are their personal motives and circumstances, as well as the actions of the regional and uezd authorities.

\section{Motives for entering state services}

In the second half of the XIX century, the number of Kazakhs who entered or wanted to enter the public service in the positions of verbal or written translators increased. All this was due to the recruitment policy pursued by the Russian Empire. On the other hand, the attitude of local Kazakhs to the position of translator has also changed. It has already become more attractive in terms of career prospects. Many Kazakhs began to send their sons to study as translators.

Some Kazakh translators of Turkestan became them in the footsteps of their fathers, who also wanted to serve the Russian government. So one of these was Sultan Asfendiyar, the son of Asfendiyar, who entered the civil service in the 30 s of the XIX century and rose to the rank of yesaul. He explains his entry into the civil service as follows: «Strictly adhering to the sacred Covenant of my father for me: to try always and in everything to serve as an example to his people in loyalty to the Russian Government» [42].

Another famous translator from the Kopal county Turdybek Syrtanov in his petition to the military Governor of Semirechensk oblast writes that his father Syrtan Bokin was personally acquainted with the military Governor of Kolpakovsky and county chief, the latter which influenced the opinion of his father about the giving of children to boarding school in Kopal to learn from the translator, «in order to make them zealous and faithful servant of the White Tsar». It was for this purpose that Turdybek and his brother Barlybek first studied at the Kopal Kyrgyz boarding school, then at the Vernyi men's gymnasium. If after 
completing his studies, Turdybek has already started a career, then his brother Bardybek graduated from the gymnasium and acquired a diploma of the I-th degree of the St. Petersburg Imperial University, where he completed a course in 2 faculties, Oriental languages and law [43;25]. It turns out that some Kazakhs desire to get a position was laid at the level of the subconscious. Their attraction to power lay in their desire to be like their ancestors.

People from ordinary families also could become translators. Such poor ordinary Kazakhs, using their knowledge and abilities, were able to get the appropriate education and skills to perform public service as an interpreter. To such officials of the Kazakhs are Satylgan Sabatayev. Having lost his parents early and experienced many difficulties in life, thanks to his efforts, he was able to get an education and get a job as a translator in the administration. Thus, he was able to realize his potential in society [44; 87]. Based on this, it should be noted that since translation activities require knowledge of languages, interpretation skills, quick thinking skills, competent oral and written speech, this way of life was a kind of «social lift» for many ordinary citizens.

Other translators also had similar motives for entering the civil service, or after graduation, they were assigned to the position of translators in one of the administrative units. They tried to take the position, first of all, of a translator, and the verbal translator was satisfied with either those who had just started their working career, or those who had no choice. Therefore, the position of a translator was more in demand and prestige among applicants. This is evidenced by numerous requests of Kazakh translators, preserved in archival materials of the Central State Archive of the Republic of Kazakhstan.

\section{Social security and awards for Kazakh translators}

Kazakh translators, as officials of the Russian administration, used certain social security conditions. The tsarist government determined the size of their salaries and canteens, as well as pensions when they retired from public service.

The materials of the Central state Archive of the Republic of Kazakhstan contain data on the amount of salaries and canteens of Kazakh officials-translators. So, in the service record of the Collegiate Registrar, translator of native languages at the Semirechensk oblast administration Turdybek Syrtanov, it is indicated that he received maintenance in the amount of 800 rubles [43; 31]. It is also known that when he resigned from public service, he was assigned a pension of 114 rubles 30 kopecks per year, which is established by law as two-thirds of its annual maintenance. However, after a petition by the translator himself, he was assigned an enhanced pension already in the amount of 214 rubles 60 kopecks per year [45; 17]. In addition, Turdybek Syrtanov has medals: silver in memory of the Holy Coronation of Their Imperial Majesties on May 14, 1896, dark bronze for his works according to the First General Census of the Empire in 1897, and silver in memory of Bose resting Emperor Alexander III of [43; 31]. In memory of the Holy Coronation of Their Imperial Majesties on May 14, 1896, at the ceremonies of which he was present in Moscow by a representative from the Naiman tribe of the Kopalsky and Lepsinsky districts of the Semirechensky and Semipalatinsk regions, he received gifts such as gold with a Crown and a chain, a gold watch and Portraits of Their Imperial Majesties in a red-silk frame, in which he has a certificate from the Military Governor of the Semirechensk oblast dated December 30, 1897 No. 6702, issued, according to the proposal of the Steppe Governor-General of December 9, 1897 years for No. 738 [43; 31].

It is also known that not all Kazakh translators received a certain uniform salary amount. In the reports of K.K. Pahlen indicated that there were two translators in the uezd administrations of Semirechensk Oblast in the state: written and verbal translators. If a written translator received a salary of 800 rubles per year, then a latter received a salary half that of a translator -400 rubles a year $[18 ; 161]$.

In addition, the content of translators also depended on their language of command. For example, if the translator of the Kyrgyz language of the Kopal District Office, the College Registrar Muhamed Ali Muratalin received 533 rubles. $33 \mathrm{k}$. salaries and 266 p. 66 c. For canteens, in total the maintenance was 800 p. per year $[46 ; 15]$, the former translator of the Manchurian and Tatar languages under the Military Governor of the Semirechensk oblast Ish-Mukhamed Ablaykhanov had a maintenance amounting to 1200 rubles per year. In addition, his enhanced pension for retirement was 800 rubles per year, instead of 285 rubles per year [47].

\section{The image of Kazakh translators}

Carrying out translation services for the Russian administration, Kazakh translators were perceived in the society inappropriately. For their Kazakh people, they were successful people who built their careers, as well as servicers of colonial authority. M. Tynyshpayev described them as follows: «Each newly arrived 
poor Kyrgyz translator a year later became rich, had herds of horses, beautiful yurts, etc.; it is not surprising that for Kyrgyz gymnasium students to be a translator became a cherished dream; the only happy exception was the deceased brothers of the Syrtanovs in Verny, for which they enjoyed well-deserved respect of both the people and the regional administration» [48].

A scientist and professor, historian Sanzhar Asfendiyarov, a native of the family of a military translator at the Turkestan general-governorship, also expressed his opinion in his writings on Kazakh translators, who, in his opinion, already had certain privileges in society in the $2^{\text {nd }}$ half of the XIX century, performing state service. The author writes: «... the imperial colonial system was the main ridge, the foundation, based on which the Kazakh elite was organized and formed in the face of the bais who were semi-feudal lords, translators and atkaminers» [49].

In addition, Russian officials were not always satisfied with the activities of Kazakh officials. They sometimes questioned the competencies or intentions of translators. In their opinion, they could deceive the participants in the dialogue and derive some benefit from them for themselves. Many Russian officials, such as Nalivkin V.P., Lykoshin N.S. and others considered local translators to be mercantile people. However, it is worth noting that their views can be influenced by the activities of all translators from among the Bashkirs and Tatars, of whom there were a lot before the formation of the Kazakh bureaucratic corps, including translators. Therefore, it can be assumed that some of their positions may be inert after all the translation services of Tatars and Bashkirs, who, according to the majority of Russian officials, in addition to the service, pursued other mercantile goals.

\section{Conclusion}

In the $2^{\text {nd }}$ half of the XIX century, the role of local translators who served the Russian Empire increased in Kazakh society. They performed a certain role in managerial affairs and were on the staff of each administrative unit. For the Russian Empire, the services of local translators on the one hand compensated for the lack of knowledge by Russian officials of «native» languages, on the other hand, strengthened the incorporation of the local population into a single management system. This trend was also in Semirechensk oblast.

There have been changes in the region in terms of perception of the position of translator by the Kazakh population. Representatives of the local population began to give their children more to study as a translator in educational institutions organized by the Russian administration, as they saw in them career prospects for the future. Therefore, the number of people wishing to enter the civil service as a translator increased. Even if there was no vacancy of a translator or interpreter in a certain Board, there were candidates for their replacement.

Translators had a salary from the state, and when they retired from service, they were assigned pensions, and sometimes, in some special cases, they were even awarded an increased pension. Many of them had insignia and orders for their diligent services of the Russian government.

However, the services of Kazakh translators were perceived inappropriately by both local Kazakhs and the Russian administration. They were successful before the Kazakhs, and at the same time «traitors,» and many condemned them, and Russian officials were not always satisfied with their translation services.

Thus, the Kazakh translators of the Semirechensk oblast carried out their activities in the administration of the Russian Empire and were part of the tsar's unified system of local government.

Tahe article is written within the framework of the grant financing project of the Ministry of Education and Science of the Republic of Kazakhstan AP05130813 «Transformation of the social organization of the Kazakh steppe: stratification and status dynamics (second half of the XVIII - 20s of the XX century)».

\section{References}

1 Материалы по истории политического строя Казахстана. - Т. 1 / Сост. канд. юрид. наук М.Г. Масевич. - АлмаАта: Изд-во АН КазССР, 1960. — 441 с.

2 Степное положение 25 марта 1891 года с объяснениями по официальным источникам. - СПб.: Изд. Земского отдела Министерства внутренних дел, 1891. - 214 с.

3 Адрес-календарь служащих в Семиреченской области на 1897 год. Изд. Семиреч. обл. стат. ком. - Верный: Типогр. Семир. обл. правл., 1897. - 99 с. 
4 Памятная книжка и адрес-календарь Семиреченской области на 1898 год. - Верный: Семиреч. обл. стат. ком., 1898. $-188 \mathrm{c}$.

5 Памятная книжка и адрес-календарь Семиреченской области на 1900 год. - Верный: Семиреч. обл. стат. ком., 1900. $-181 \mathrm{c}$.

6 Памятная книжка и адрес-календарь Семиреченской области на 1901 год - Верный: Семиреч. обл. стат. ком., 1901. $-242 \mathrm{c}$.

7 Памятная книжка и адрес-календарь Семиреченской области на 1905 год. - Верный: Семиреч. обл. стат. ком., 1905. $-393 \mathrm{c}$.

8 Список лиц гражданского и других ведомств, служащих в Семиреченской области. 1902 г. (по сведениям до 1-го Мая). - Верный: Типогр Семиреч. обл. правл., 1902. - 122 с.

9 Список лиц. гражданского и духовного ведомств, служащих в Туркестанском крае. [Текст]: 1900 год. — Ташкент: Типо-лит. бр. Порцевых, 1900. — 200 с.

10 Список лиц. гражданского и духовного ведомств, служащих в Туркестанском крае. [Текст]: 1901 г.. — Ташкент: Типо-лит. бр. Порцевых, 1901. - 206 с.

11 Список лиц. гражданского и духовного ведомств, служащих в Туркестанском крае. [Текст]: 1902 г. — Ташкент: Типо-лит. бр. Порцевых, 1902. - 212 с.

12 Ягелло Н.Л. Сборник материалов по вопросу об изучении туземных языков служащими по военно-народному управлению Туркестанского края / Н.Л. Ягелло. — Ташкент, 1906. — 239 с.

13 Туркестан в имперской политике России: моногр. в документах / отв. ред. Т.В. Котюкова. — М., 2019. — 2078 с.

14 Судебная часть в Туркестанском крае и степных областях / Сост. ст. сов. Тургайск. обл. И.И. Крафт. - Оренбург, 1898. - $234 \mathrm{c}$.

15 Румянцев П.П. Киргизский народ в прошлом и настоящем / П.П. Румянцев. - СПб., 1910. - 65 с.

16 Гинс Г.К. В киргизских аулах / Г.К. Гинс // Исторический вестн. — М.: Вост. лит., 1913. — № 10. — 49 с.

17 Областное управление. Отчет по ревизии Туркестанского края, произведенной по Высочайшему повелению Сенатором Гофмейстером Графом К.К. Паленом. Областное управление. - СПБ., 1910. - 353 с.

18 Уездное управление. Отчет по ревизии Туркестанского края, произведенной по Высочайшему повелению Сенатором Гофмейстером Графом К.К. Паленом. Областное управление. - СПБ., 1910. - 168 с.

19 Наливкин В.П. Туземцы раньше и теперь / В.П. Наливкин. - Ташкент: Электрическая типо-литография Туркестанского Товарищества печатного дела, 1913. - 144 с.

20 Лыкошин Н.С. Полжизни в Туркестане. Очерки быта туземного населения / Н.С. Лыкошин. - Петроград: Типогр. Б.Д. Брунера, 1916. - 415 с.

21 Рыскулов Т. Восстание туземцев в Средней Азии в 1916 году: [В 2-х ч.] / Т. Рыскулов. — Кзыл-Орда: Гос. изд-во КССР, 1927. - $124 \mathrm{c}$

22 Асфендияров С.Д. Национально-освободительное восстание 1916 года в Казахстане / С.Д. Асфендияров. - АлмаАта - Москва: Казахстанское краевое изд-во, 1936. - 150 с.

23 Султангалиева Г.С. Татарские и башкирские служащие в казахской степи (XVШ-XIX вв.) / Г.С. Султангалиева // Этнопанорама. - 2000. - С. 48-54; Султангалиева Г.С. Деятельность башкирских переводчиков и письмоводителей в Казахстане в процессе взаимодействия культур (XVIII-XIX вв.) / Г.С. Султангалиева // Ватандаш. — 2005. - С. 73-78.; Казахские чиновники на службе Российской империи: сб. док. и материалов / Сост.: Г.С. Султангалиева, Т.Т. Далаева, С.К. Удербаева. - Алматы: Қазақ ун-ті, 2013. — 363 с.

24 Қойгелдиев М. Жетісудағы Ресей билігі (ХІХ ғ. — 1917 ж.) / М. Қойгелдиев. — Астана: Елорда, 2004. — 216 б.

25 Макажанова 3.Ш. Политика российских властей по подготовке кадров для управленческого аппарата (60-90-е годы XIX в.) / З.Ш. Макажанова // Вестн. КазНПУ им. Абая. Сер. Исторические и социально-политические науки. - 2004. C. $46-50$.

26 Айтмуханбетов А.А. Казахские переводчики в системе делопроизводства Российской империи (XIX - нач. XX вв.) / А.А. Айтмуханбетов // Вестн. Атырау. гос. ун-та им. Х. Досмухамедова. - 2009. - № 3(14). - С. 30-32.

27 Адельбаева Н.А. Особенности формирования и становления школьного образования в Семиреченской и Сырдарьинской областях в XIX - нач. ХХ вв / Н.А. Адельбаева // Вестн. ЗКГУ. — 2010. — № 4. — С. 145-154.

28 Сактаганова З.Г. К 100-летию национально-освободительного движения: о причинах восстания казахов 1916 года / З.Г. Сактаганова // Вестн. Караганд. ун-та. Сер. История. Философия. — 2016. — № 4(84). — С. 96-104.

29 Удербаева С.К. Деятельность и полномочия казахского чиновничества Туркестанского генерал-губернаторства / С.К. Удербаева // Қазақстан Республикасы Ұлттық Ғылым Академиясының Хабарлары = Известия Национальной академии наук Республики Казахстан. - 2016. - № 4. - С. 144-153.

30 Ильясов Ш.А. Деятельность административного аппарата в системе органов колониального управления Степного края (1891-1917 гг.): дис. ... д-ра филос. PhD / Ш.А. Ильясов. — 2017. — 181 с.

31 Шушкова М.Е. Организация управления Туркестаном в начале XX века: дис. ... канд. истор. наук: 07.00 .02 - «Отечественная история» / Маргарита Евгеньевна Шушкова . - М., 2016. — 313 с.

32 Сумарокова О.Л. К вопросу о лингвистической подготовке административных служащих Туркестанского края / О.Л. Сумарокова // Власть. - 2016. — № 2. - С. 169-173.

33 Алимджанов Б.А. Экономическая политика Российской империи в Туркестанском генерал-губернаторстве (вторая половина XIX — нач. XX вв.) / Б.А. Алимджанов. - СПб., 2016. — 376 с. - С. 70,71.

34 Плоских В.М. Сыдыков: героическая и трагическая судьба переводчика периода восстания 1916 г. / В.М. Плоских // Вестн. КРСУ. - 2016. - Т. 16. - № 10. - С. 205-210. 
35 Кулиева Ш.А. Переводческое дело в Центрально-Азиатском регионе: страницы истории (XVI-XIX вв.) / Ш.А. Кулиева, Д.В. Тавберидзе // Вестн. РУДН. Сер. Вопросы образования: языки и специальность. — 2017. - Т. 14. - № 2. - C. 310-318.

36 Talant Mawkanuli, Virginia Martin. Nineteenth Century Kazak Correspondence with Russian Authorities: Morphemic Analysis and Historical Contextualization. Central Eurasian Studies Review. — 2009. — Vol. 8, No. 1. — 21-28 p.

37 Adeeb Khalid. Culture and power in colonial Turkestan, Cahiers d'Asie Centrale 17/18, in: S. Gorshenina and S. Abashin (Eds). Le Turkestan Russe, un colonie comme les autres? (Tashkent-Paris: IFEAC, 2009). — P. 418.

38 Campbell I.W. Knowledge and the ends of empire: Kazak intermediaries and Russian rule on the steppe, 1731-1917 / I.W. Campbell. — New York: Cornell University Press, 2017. — 273 p.

39 Daniel Brower. Turkestan and the fate of the Russian Empire / Brower Daniel . - Londres-New York, Routledge Curzon, 2003. $-213 \mathrm{p}$

40 Записки Н.О. фон Розенбаха / Н.О. Записки // Русская старина. — 1916. — № 5. - С. 173-239.

41 Дмитриев C.В. Материалы по этнографии и фольклору казахов из фонда генерала Н.И. Гродекова / Лавровский сб.: материалы XXXIV и XXXV Среднеазиатско-Кавказских чтений, 2010-2011 гг.: Этнология, история, археология, культурология / Отв. ред. Ю.Ю. Карпов, М.Е. Резван; РАН. МАЭ им. Петра Великого (Кунсткамера). - СПб.: МАЭ РАН, 2011. - C. 86-92.

42 Автобиография бывшего переводчика канцелярии Туркестанского Генерала-губернатора Асфендиярова. [Электронный ресурс]. - Режим доступа: https://mytashkent.uz/2013/12/10/avtobiografiya-by-vshego-perevodchika-kantselyariiturkestanskogo-gen-guber-asfendiyarova/

43 Центральный государственный архив Республики Казахстан. - Ф. 44. — Оп. 1. — Д. 1804. — Л. 35.

44 Казахи в России: Биографический сб.: [В 2-х т.]. — М.: Вега, 2008. — 308 с.

45 Центральный государственный архив Республики Казахстан. - Ф. 44. - Оп. 1. — Д. 2173. — Л. 20.

46 Центральный государственный архив Республики Казахстан. - Ф. 44. — Оп. 1. — Д. 1890. — Л. 15.

47 Сатенова М.Р. Наброски к портрету султана Иш-Мухаммеда Аблайханова. [Электронный ресурс] / М.Р. Сатенова. Режим доступа: http://iie.kz/? p=4213

48 Из Протокола допроса мировым судьей 4-го участка Черняевского у. инженера М. Тынышпаева об истории взаимоотношений российской власти с казахами. [Электронный ресурс]. - Режим доступа: https://qamba.info/site/book/online/qazaq-ult-azattyq-qzghalysy-ii-kitap/content/content_4.xhtml/ $304 \mathrm{c}$.

49 Асфендияров С.А. История Казахстана (с древнейших времен) / С.А. Асфендияров. — Алматы: Санат, 1998.

\title{
М. Абдрахим
}

\section{Жетісу облысының қазақ аудармашылары}

\begin{abstract}
Мақалада Жетісу облысы әкімшілігі құрылымында қызмет еткен қазақ аудармашыларының қызметі талқыланған. Автор өлкенің шенеуніктерінің қазақ аудармашыларына қатысты ұстанымдарын жанжақты қарастырған, жергілікті аудармашылардың әлеуметтік шығу тегі, олардың мемлекеттік қызметке араласуындағы талаптары мен уәждері қарастырылған. Сонымен қатар, облыс әкімшілігінде қызмет еткен қазақ аудармашыларының бейнесі талданған.
\end{abstract}

Кілт сөздер: аудармашы, Жетісу облысы, қазақ шенеуніктері, аймақтық басқару, шен, қызмет, қазақ аудармашылары.

\section{М. Абдрахим}

\section{Переводчики-казахи из Семиреченской области}

В статье рассмотрена деятельность казахских переводчиков, которые служили в структуре администрации Семиреченской области. Автором были всесторонне рассмотрены позиции чиновников края относительно казахских переводчиков, изучены социальное происхождение местных переводчиков, их жалованья и мотивы поступления на государственную службу. Кроме того, проанализированы образы казахских переводчиков, которые служили в администрации области.

Ключевые слова: переводчик, Семиреченская область, казахские чиновники, региональная администрация, чин, должность, переводчики-казахи.

\section{References}

1 Masayevich, M.G. \& et al. (1960). Materialy po istorii politicheskoho stroia Kazakhstana [Materials on the history of the political system of Kazakhstan]. Alma-Ata: Izdatelstvo Akademii nauk KazSSR [in Russian]. 
2 Stepnoe polozhenie 25 marta 1891 hoda s obiasneniiami po ofitsialnym istochnikam [Steppe position March 25, 1891 with explanations from official sources]. (1891). Saint-Petersburg: Izdanie Zemskoho otdela Ministerstva vnutrennikh del [in Russian].

3 Adres-kalendar sluzhashchikh v Semirechenskoi oblasti na 1897 hod [The address calendar of employees in the Semirechensk region for 1897]. (1897). Vernyi: Izdanie Semirechenskoho Oblastnoho Statisticheskoho Komiteta [in Russian].

4 Pamiatnaia knizhka i adres-kalendar Semirechenskoi oblasti na 1898 hod [Memorial book and address calendar of the Semirechensk region for 1898]. (1898). Vernyi: Izdanie Semirechenskoho oblastnoho statisticheskoho komiteta [in Russian].

5 Pamiatnaia knizhka i adres-kalendar Semirechenskoi oblasti na 1900 hod [Memorial book and address calendar of the Semirechensk region for 1900]. (1900). Vernyi: Izdanie Semirechenskoho oblastnoho statisticheskoho komiteta [in Russian].

6 Pamiatnaia knizhka i adres-kalendar Semirechenskoi oblasti na 1901 hod [Memorial book and address calendar of the Semirechensk region for 1901]. (1901). Vernyi: Izdanie Semirechenskoho oblastnoho statisticheskoho komiteta [in Russian].

7 Pamiatnaia knizhka i adres-kalendar Semirechenskoi oblasti na 1898 hod [Memorial book and address calendar of the Semirechensk region for 1905]. (1905). Vernyi: Izdanie Semirechenskoho oblastnoho statisticheskoho komiteta [in Russian].

8 Spisok lits hrazhdanskoho i druhikh vedomstv, sluzhashchikh v Semirechenskoi oblasti. 1902 h.: (Po svedeniiam do 1-ho maia) [The list of persons of civil and other departments serving in the Semirechensk region. 1902: (According to information before May 1)]. (1902). Vernyi: Izdanie Semirechenskoho oblastnoho statisticheskoho komiteta [in Russian].

9 Spisok lits hrazhdanskoho i dukhovnoho vedomstv, sluzhashchikh v Turkestanskom krae [Tekst]: 1900 hod [List of persons of civil and spiritual departments serving in the Turkestan region [Text]: 1900]. (1900). Tashkent: Tipo-litohrafiia br. Tortsevykh [in Russian].

10 Spisok lits hrazhdanskoho i dukhovnoho vedomstv, sluzhashchikh v Turkestanskom krae [Tekst]: 1901 hod [List of persons of civil and spiritual departments serving in the Turkestan region [Text]: 1901]. (1901). Tashkent: Tipo-litohrafiia br. Tortsevykh [in Russian]

11 Spisok lits hrazhdanskoho i dukhovnoho vedomstv, sluzhashchikh v Turkestanskom kraie [Tekst]: 1902 hod [List of persons of civil and spiritual departments serving in the Turkestan region [Text]: 1902]. (1902). Tashkent: Tipo-litohrafiia br. Tortsevykh [in Russian].

12 Yagello, N.L. (1906). Sbornik materialov po voprosu ob izuchenii tuzemnykh yazykov sluzhashchimi po voyennonarodnomu upravleniyu Turkestanskoho kraia [Compendium of materials on the study of native languages by employees of the military public administration of the Turkestan region]. Tashkent: Tipohrafia pri Kantseliarii Turkestanskoho heneral-hubernatora [in Russian].

13 Kotiukova, T.V. (Eds.). (2019). Turkestan v imperskoi politike Rossii [Turkestan in the imperial policy of Russia]. Moscow: Kuchkovo pole [in Russian]

14 Kraft, I.I. (1898). Sudebnaia chast $v$ Turkestanskom krae i stepnykh oblastiakh [The trial in Turkestan and the steppe regions]. Orenburg [in Russian].

15 Rumyantsev, P.P. (1910). Kirhizskii narod v proshlom i nastoiashchem [Kyrgyz people in the past and present]. SaintPetersburg [in Russian].

16 Gins, G.K. (1913). V kirhhizskikh aulakh [In kirghiz villages]. Istoricheskii vestnik - Vostochnaia literatura - Historical Bulletin-Oriental literature, 10, 49-50 [in Russian].

17 Palen, K.K. (1910). Oblastnoe upravlenie. Otchet po revizii Turkestanskoho kraia, proizvedennoi po Vysochayshemu poveleniiu Senatorom Hofmeisterom Hrafom K.K. Palenom. Oblastnoie upravleniie 「Oblast administration. Report on the audit of the Turkestan region, carried out at the Highest Command by Senator Hoffmeister Earl K.K. Pahlen. Oblast administration]. SaintPetersburg: Senatskaia tipohrafia [in Russian].

18 Palen, K.K. (1910). Uezdnoie upravleniie. Otchet po revizii Turkestanskoho kraia, proizvedennoi po Vysochaishemu poveleniyu Senatorom Hofmeisterom Hrafom K.K. Palenom. Oblastnoie upravleniie [Uezd administration. Report on the audit of the Turkestan region, carried out at the Highest Command by Senator Hoffmeister Earl K.K. Pahlen. Oblast administration]. SaintPeterburg: Senatskaia tipohrafia [in Russian].

19 Nalivkin, V.P. (1913). Tuzemtsy ranshe i teper [Natives before and now]. Tashkent: Elektricheskaia tipo-litohrafiia Turkestanskoho tovarishchestva pechatnoho dela [in Russian].

20 Lykoshin, N.S. (1916). Polzhizni v Turkestane. Ocherki byta tuzemnoho naseleniia [Half life in Turkestan. Essays on the life of the native population]. Petrograd: Tipohrafiia B.D. Brunera [in Russian].

21 Ryskulov, T. (1927). Vosstanie tuzemtsev v Srednei Azii v 1916 hodu: [V dvukh chastyak] [The revolt of the natives in Central Asia in 1916. In two parts]. Kzyl-Orda: Hosudarstvennoe izdatelstvo K.S.S.R. [in Russian].

22 Asfendiyarov, S.D. (1936). Natsionalno-osvoboditelnoie vosstanie 1916 hoda v Kazakhstane [National Liberation Uprising of 1916 in Kazakhstan]. Alma-Ata-Moscow: Kazakhstanskoie kraievoie izdatelstvo [in Russian].

23 Sultangaliyeva, G.S. (2010). Tatarskie i bashkirskie sluzhashchie v kazakhskoi stepi (XVIII-XIX vv.) 「Tatar and Bashkir employees in the Kazakh steppe (XVIII-XIX centuries)]. Etnopanorama - Ethnic Panorama, 48-54; Sultangaliyeva, G.S. (2005). Deiatelnost bashkirskikh perevodchikov i pismovoditeley $\mathrm{v}$ Kazakhstane $\mathrm{v}$ protsesse vzaimodeistviia kultur (XVIII-XIX vv.) 「The activities of Bashkir translators and writers in Kazakhstan in the process of interaction of cultures (XVIII-XIX centuries)]. Vatandash - Compatriot, 73-78.; Sultangaliyeva, G.S., Dalayeva, T.T., \& Uderbayeva, S.K. (2013). Kazakhskie chinovniki na sluzhbe Rossiiskoi imperii [Kazakh officials in the service of the Russian Empire]. Almaty: Kazakh universiteti [in Russian].

24 Koigeldiyev, M. (2004). Zhetisudahy Resei bilihi (XIX h. - 1917 zh.) [The Russian authority in Zhetysu (XIX - 1917)]. Astana: Elorda [in Kazakh].

25 Makashanova, Z.Sh. (2004). Politika rossiiuskikh vlastei po podhotovke kadrov dlia upravlencheskoho apparata (60-90e hody XIX v.) 「The policy of the Russian authorities in training personnel for the administrative apparatus (60-90s of the XIX century) l. Vestnik KazNPU imeni Abaia. Seriia «Istoricheskie i sotsialno-politicheskie nauki» — Bulletin of KazNPU named after Abay, a series of «Historical and socio-political sciences», 46-50 [in Russian].

26 Aitmukhanbetov, A.A. (2009). Kazakhskie perevodchiki v sisteme deloproizvodstva Rossiyskoi imperii (XIX-nach. XX vv.) [Kazakh translators in the clerical system of the Russian Empire (XIX-early XX centuries)]. Vestnik Atyrauskoho hosudarstvennoho 
universiteta imeni Kh. Dosmukhamedova - Bulletin of Atyrau State University named after Kh. Dosmukhamedov, 3, 30-32 [in Russian].

27 Adelbayeva, N.A. (2010). Osobennosti formirovaniia i stanovleniia shkolnoho obrazovaniia v Semirechenskoi i Syrdarinskoi oblastiakh v XIX - nachale XX vv. [Features of the formation and formation of school education in the Semirechensk and Syrdarya regions in the XIX - early XX centuries]. Vestnik ZKHU - Bulletin of WKSU, 4, 145-154 [in Russian].

28 Saktaganova, Z.G. (2016). K 100-letiiu natsionalno-osvoboditelnoho dvizheniia: o prichinakh vosstaniia kazakhov 1916 hoda 「On the 100th anniversary of the national liberation movement: on the causes of the Kazakh uprising of 1916]. Vestnik Karahandinskoho universiteta. Seriia «Istoriia. Filosofiia» - Bulletin of the Karaganda University. Series of «History. Philosophy», 4, 96-104 [in Russian].

29 Uderbayeva, S.K. (2016). Deiatelnost i polnomochiia kazakhskoho chinovnichestva Turkestanskoho Heneral-hubernatorstva 「Activities and powers of the Kazakh officials of the Turkestan General-Governorship]. Izvestiia natsionalnoi akademii nauk Respubliki Kazakhstan - News of the National Academy of Sciences of the Republic of Kazakhstan, 4, 144-153 [in Russian].

30 Ilyasov, Sh.A., \& Ilyasov Sh.A. (2017). The activities of the administrative apparatus in the system of colonial authorities of the Steppe Territory (1891-1917) 「The activities of the administrative apparatus in the system of colonial authorities of the Steppe Territory (1891-1917)]. Doctor's thesis. [in Russian].

31 Shushkova, M.Y. (2016). Orhanizatsiia upravleniia Turkestanom v nachale XX veka [Organization of Turkestan management in the early XX century]. Candidate's thesis. Moscow [in Russian].

32 Sumarokova, O.L. (2016). K voprosu o linhvisticheskoi podhotovke administrativnykh sluzhashchikh Turkestanskoho kraia [On the issue of linguistic training of administrative employees of the Turkestan Territory]. Vlast - Authority, 2, 169-173 [in Russian].

33 Alimzhanov, B.A. (2016). Ekonomicheskaia politika Rossiiskoi imperii v Turkestanskom Heneral-hubernatorstve (vtoraia polovina XIX - nachalo XXvv.) /The economic policy of the Russian empire in the Turkestan governor-general (second half of the 19 th - beginning of the 20th centuries)]. Saint-Petersburg [in Russian].

34 Ploskikh, V.M. (2016). Sydykov: heroicheskaia i trahicheskaia sudba perevodchika perioda vosstaniia 1916 h. 「Sydykov: the heroic and tragic fate of the translator of the 1916 uprising]. Vestnik KRSU - Bulletin of KRSU, Vol. 16, 10, 205-210 [in Russian].

35 Kuliyeva, Sh.A., \& Tavberidze, D.V. (2017). Perevodcheskoe delo v Tsentralno-Aziatskom rehione: stranitsy istorii (XVIXIX veka) [Translation business in the Central Asian region: pages of history (XVI - XIX centuries)]. Vestnik RUDN. Seriia: Voprosy obrazovaniia: yazyki $i$ spetsialnost - Bulletin of PFUR. Series: Education issues: languages and specialty, Vol. 14, 2, $310-$ 318 [in Russian].

36 Mawkanuly, T. \& Martin, V. (2009). Nineteenth Century Kazak Correspondence with Russian Authorities: Morphemic Analysis and Historical Contextualization. Central Eurasian Studies Review, Vol. 8, No. 1, 21-28.

37 Khalid, A. (2009). Culture and power in colonial Turkestan, Cahiers d'Asie Centrale 17/18, in: S. Gorshenina and S. Abashin (Eds). Le Turkestan Russe, un colonie comme les autres? (Tashkent-Paris: IFEAC, 2009).

38 Campbell, I.W. (2017). Knowledge and the ends of empire: Kazak intermediaries and Russian rule on the steppe, $1731-1917$. New York: Cornell University Press.

39 Brower, D. (2003). Turkestan and the fate of the Russian Empire. Londres-New York: Routledge Curzon.

40 Zapiski, N.O. fon-Rozenbakha [Notes of N.O. von Rosenbach]. Russkaia starina — Russian antiquity, 5, 173-239 [in Russian].

41 Dmitriyev, S.V. (2011). Materialy po etnohrafii i folkloru kazakhov iz Fonda henerala N.I. Grodekova [Materials on ethnography and folklore of Kazakhs from the fund of General N.I. Grodekova]. Proceedings from Lavrovsky collection: $X X X I V i X X X V$ Sredneaziatsko-Kavkazskikh chteniy, 2010-2011 h.: Etnolohiia, istoriia, arkheolohiia, kulturolohiia - XXXIV and XXXV of the Central Asian-Caucasian readings, 2010-2011: Ethnology, History, Archeology, Cultural Studies. (pp 86-92). Saint Petersburg [in Russian].

42 Avtobiohrafiia byvsheho perevodchika Kantseliarii Turkestanskoho Hen.-huber. Asfendiiarova [Autobiography of a former translator of the office of Turkestan Gen.-Govern. Asfendiyarov]. (n.d.). mytashkent.uz. Retrieved from https:/mytashkent.uz/2013/12/10/avtobiografiya-by-vshego-perevodchika-kantselyarii-turkestanskogo-gen-guber-asfendiyarova/ [in Russian].

43 Tsentralnyy Hosudarstvennyy Arkhiv Respubliki Kazakhstan [The Central State Archive of the Republic of Kazakhstan]. Fund 44, Inventory 1, File 1804, P. 35 [in Russian].

44 Kazakhi v Rossii: Biohraficheskii sbornik : [V 2-kh t.]. [Kazakhs in Russia: Biographical digest in 2 vols.]. (Vol. 10). (2008). Moscow: Veha [in Russian].

45 Tsentralnyi hosudarstvennyi arkhiv Respubliki Kazakhstan [The Central State Archive of the Republic of Kazakhstan]. Fund 44, Inventory 1, File 2173, P. 20 [in Russian].

46 Tsentralnyi hosudarstvennyi arkhiv Respubliki Kazakhstan [The Central State Archive of the Republic of Kazakhstan]. Fund 44, Inventory 1, File 1890, P. 15 [in Russian].

47 Satenova, M.R. Nabroski k portretu sultana Ish-Mukhammeda Ablaykhanova [Outline for the portrait of Sultan IshMuhammad Ablaihanov]. (n.d.). iie.kz. Retrieved from http://iie.kz/? p=4213 [in Russian].

$48 \mathrm{Iz}$ Protokola doprosa mirovym sudei 4-ho uchastka Cherniaevskoho u. inzhenera M. Tynyshpaeva ob istorii vzaimootnoshenii rossiiskoi vlasti s kazakhami [From the protocol of interrogation by the magistrate of the 4th section of Chernyaevsky u. engineer M. Tynyshpaev about the history of relations between the Russian government and the Kazakhs]. (n.d.). qamba.info. Retrieved from https://qamba.info/site/book/online/qazaq-ult-azattyq-qzghalysy-ii-kitap/content/content_4.xhtml/ [in Russian].

49 Asfendiyarov, S.A. (1998). Istoriia Kazakhstana (s drevneyshikh vremen) [History of Kazakhstan (since ancient times)]. Almaty: Sanat [in Russian]. 